\title{
IMPLEMENTASI PEMBERDAYAAN ZAKAT \\ DI MASJID AGUNG JAWA TENGAH \\ DALAM KAJIAN UNDANG-UNDANG NO. 23 TAHUN 2011 TENTANG PENGELOLAAN ZAKAT
}

\author{
Nurjanah Nurjanah \\ Magister Hukum Universitas Semarang
}

\begin{abstract}
ABSTRAK
Tujuan dari penelitian ini adalah untuk menganalisa Lembaga Amil Zakat sebagai salah satu organisasi atau lembaga berperan untuk mengoptimalkan pemberdayaan zakat yang belum mampu untuk membantu pemerintah dalam mengentaskan kemiskinan. Penelitian ini diarahkan untuk menjawab dua masalah yaitu bagaimana implementasi pemberdayaan zakat di masjid Agung Jawa Tengah dalam kajian Undang-Undang No. 23 Tahun 2011 tentang pengelolaan zakat dan bagaimana kendala dan solusi atas pemberdayaan zakat yang dijalankan di masjid Agung Jawa Tengah dalam kajian Undang-Undang No. 23 Tahun 2011 tentang pengelolaan zakat. Metode yang digunakan dalam penelitian ini adalah penelitian yuridis normatif. Tanggungjawab dari pengelola Lazisma lainnya dalam bidang pendidikan, kesehatan, ekonomi dan lainnya telah dilaksanakan sesuai dengan tujuan pemberdayaan zakat dalam mengentaskan kemiskinan secara keseluruhan. Kendala yang dihadapinya antara lain: masih banyak muzakki yang masih enggan untuk membayar zakat; Kepercayaan masyarakat kurang; Sosialisasi kepada masyarakat masih kurang optimal. Solusi untuk mengantisipasinya, meliputi: Melakukan pembinaan regulasi tentang kewajiban zakat bagi Muzakki; penguatan kepada amil zakat untuk selalu bersikap jujur dan professional; mensinergikan dan saling kerjasama antara lapisan masyarakat, pemerintah, tokoh agama dan juga para amil zakat.
\end{abstract}

Kata kunci: zakat; pengentasan kemiskinan; lembaga amil zakat. 


\title{
IMPLEMENTATION OF ZAKAT EMPOWERMENT IN MASJID AGUNG CENTRAL JAVA IN LAW NO. 23 OF 2011 ABOUT ZAKAT MANAGEMENT
}

\author{
Nurjanah Nurjanah \\ Master of Law, University of Semarang
}

\begin{abstract}
The purpose of this study is to analyze Amil Zakat Institute as one of organization or institution has role to optimize the empowerment of zalcat which have not yet able to assist government in alleviating poverty as a whole as the main goal in zakat management. This research is directed to answer two problem that is how the implementation of zakat empowerment in Central Java Mosque in study of Law No. 23 of 2011 on the management of zakat and how the constraints and solutions to the empowerment of zakat that is run in the Great Mosque of Central Java in the review of Law No. 23 of 2011 on the management of zakat. The method used in this research is normative juridical research. The responsibilities of other Lazisma managers in education, health, economics and others have been implemented in accordance with the objective of zakat empowerment in alleviating poverty as a whole. Constraints faced include: there are still many muzakki are still reluctant to pay zakat; Public trust is lacking; Socialization to the community is still less than optimal. Solutions to anticipate, including: Conducting regulatory guidance on the obligations of zakat for Muzakki; strengthening to amil zakat to always be honest and professional; synergize and mutual cooperation between layers of society, government, religious leaders and also the amil zakat.
\end{abstract}

Keywords: zakat; poverty alleviation; amil zakat institution. 


\section{A. PENDAHULUAN}

Badan Amil Zakat Nasional (Baznas) Provinsi Jawa Tengah merupakan bentukan masyarakat atau berada dibawah lembaga tertentu yang tidak ada kaitannya dengan pemerintah. Hal ini berguna untuk mengetahui apakah masyarakat mempunyai respon positif untuk melaksanakan (membayar) zakat, dan bagaimana lembaga itu secara professional melaksanakan tugas pengelolaan zakat sebagai upaya pengentasan kemiskinan. ${ }^{1}$

Zakat dalam ajaran Islam merupakan pilar (rukun) yang wajib ditunaikan terhadap harta yang telah mencapai nishab. Menurut fiqih Islam, zakat itu wajib bagi setiap muslim yang merdeka. Zakat merupakan rukun Iman ketiga dalam rukun Islam. Dalam Islam zakat dapat diartikan sebagai harta yang wajib dikeluarkan apabila telah mencapai ketentuan-ketentuan dalam berzakat yang ditentukan dalam ajaran Islam.

Yang dimaksud zakat fitrah adalah zakat jiwa yang wajib dikeluarkan setiap tahun pada bulan Ramadlan. Sedangkan zakat mal adalah zakat harta kekayaan yang wajib dikeluarkan bagi orang Islam apabila zakat tersebut telah mencapai syarat yang ditentukan dalam Islam untuk dizakati.

Kelompok yang ditetapkan Allah yang berhak mendapat zakat dapat dilihat dalam surat At-Taubah ayat 60 yang artinya : " sesungguhnya zakatzakat itu hanyalah untuk orang-orang fakir dan miskin, pengurus (amil) zakat, para mua'allaf yang dibujuk hatinya untuk memerdekakan budak, orang-orang yang berhutang, untuk usaha dijalan Allah dan untuk orangorang yang sedang perjalanan, sebagai ketetapan yang diwajibkan Allah dan Allah Maha Mengetahui dan Maha Bijaksana.” (QS. At-Taubah :60 ).

${ }^{1}$ Abdul Aziz, Pendayagunaan Zakat Sebagai Upaya Pengentasan Kemiskinan, Jurnal Ius Constituendum Vol 1 No 1, Magister Hukum Universitas Semarang, 2016, Semarang, hlm 88 . 
Zakat berdasar ayat tersebut sebagai jaminan sosial bagi kelompok yang sangat membutuhkan bantuan materi. Dengan zakat merupakan ibadah yang mempunyai peran strategis dalam konteks ekonomi keumatan yang akan memberi dampak kesejahteraan dan kemakmuran orang banyak.

Hukum tidak hanya berkaitan dengan segi lahiriah dari manusia juga dari segi batiniah, berdasarkan Pasal 29 ayat (2) UUD'45 maka lahirlah Undang-Undang No.23 Tahun 2011 tentang pengelolaan zakat salah satunya adalah adannya Lembaga Amil Zakat Masjid Agung Jawa Tengah sebagai lembaga yang dibentuk oleh masyarakat khususnya untuk kota Semarang.

Kebutuhan paling mendasar dan penting dalam sistem kehidupan manusia adalah permasalahn ekonomi. Faktor ekonomi merupakan tolak ukur keberhasilan seseorang bahkan sebagai tolak ukur keberhasilan pemerintah. Kemiskinan dapat digolongkan menjadi tiga yaitu kemiskinan struktural, kemiskinan kultural dan kemiskinan natural.

Menurut Didin Hafidhuddin menurut pendapatnya tentang zakat pengertian “ zakat adalah ibadah maatiyyah ijtima'iyah, ibadah yang berkaitan dengan harta yang memiliki kedudukan dan posisi penting dalam meningkatkan kesejahteraan masyarakat,apabila dikelola dengan baik, amanah dan sesuai dengan syariah Islamiyah baik pengambilannya maupun pendistribusiannya. $^{2}$

Perlindungan dan jaminan menjalankan ibadah sesuai dengan agamanya dalam konstitusi Pasal 29 ayat (2) UUD 1945 yang telah melahirkan Undang-Undang No. 23 Tahun 2011 tentang pengelolaan Zakat (UU-PZ) yang membawa “ angin segar “ dalam kehidupan. Konsekuensi yuridisnya masalah zakat yang selama ini dianggap masalah ibadah (ritual individu) kini menjadi masalah hukum, ekonomi dan politik hukum bahkan dalam jangka panjang dengan adanya UU-PZ terutama dikalangan

\footnotetext{
${ }^{2}$ Didin Hafidhuddin, Islam Aplikatif, Gema Insani, 2003, hlm. 245.
} 
Cendikiawan dan Ulama sebagai sarana untuk mengatasi kemiskinan khususnya Kota Semarang.

Lembaga Amil Zakat Masjid Agung Jawa Tengah berdiri berdasarkan SK Gubernur Jawa Tengah No. 71 Tahun 2003. Hasil dana zakatnya disalurkan kepada delapan asnaf dan program lain seperti program reguler diantaranya untuk pendidikan, beasiswa dlu'afa sedang program isidental terdiri dari distribusi hewan qurban, bantuan kemanusiaan, penyantunan anak yatin dan lainya.

Akan tetapi dana zakat yang dilakukan LAZ masjid Agung Jawa Tengah belum signifikan jika dibandingkan dengan jumlah penduduk muslim kota Semarang. Hal ini dapat berefek pada jumlah dana yang disalurkan dan jumlah penerima zakat (mustahik). Karena semakin banyak dana zakat efek positifnya dapat dirasakan para mustahik yaitu untuk meningkatkan kualitas hidup mustahik.

Penghimpunan dana tidak maksimal di LAZ masjid Agung Jawa Tengah ada beberapa faktor antara lain kinerja LAZ masjid Agung Jawa Tengah kurang maksimal, kurangnya sosialisasi pemerintah agar masyarakat memberikan dana zakat kepada lembaga atau Badan Amil Zakat, pemerintah tidak memiliki kebijakan khusus untuk menjadikan zakat sebagai satu-satunya penerimaan negara. Hal ini sangat disayangkan karena zakat adalah salah satu rukun Islam yang wajib dilaksanakan oleh umat Islam, dimana mayoritas dari penduduk Indonesia beragama Islam. Zakat berfungsi sebagai alat pengentas kemiskinan dan pensejahtera umat.

Untuk menjalankan tujuan dan fungsi zakat dengan baik dan benar keberadaan LAZ Masjid Agung Jawa Tengah juga harus bekerja pro-aktif memiliki program-program dan perencanaan yang jelas berkesinambungan, memiliki sistem manajemen dan mekanisme kerja yang kredibel dan akuntabel ( dapat dipertanggungjawabkan). Disinilah peran LAZ dimasjid Agung Jawa Tengah untuk mengentaskan kemiskinan di kota Semarang khususnya. Disisi lain LAZ masjid Agung jawa Tengah harus menjalankan 
prinsip-prinsip manajemen modern dan harus dikontrol oleh masyarakat. Selain itu peran dan dukungan pemerintah dalam peningkatan pelaksanaan zakat mutlak diperlukan, sebab kedudukan pemerintah (ulil amri) secara umum menurut pandangan hukum Islam harus bertanggungjawab terhadap kesejahteraan rakyat.

Keberhasilan zakat sebagai alat pensejahtera umat dan menyebabkan fungsi zakat dapat dirasakan sebagai suatu pengaruh yang besar dalam meningkatkan taraf perekonomian masyarakat kota Semarang.

\section{B. PERMASALAHAN}

Berpijak dari latar belakang penelitian sebagaimana yang diuraikan diatas, dalam penelitian ini pokok permasalahan yang akan dikaji lebih lanjut dirumuskan sebagai berikut :

1. Bagaimana implementasi pemberdayaan zakat di masjid Agung Jawa Tengah dalam kajian Undang-Undang No. 23 Tahun 2011 tentang pengelolaan Zakat?

2. Bagaimana kendala dan solusi atas pemberdayaan zakat yang dijalankan di Masjid Agung Jawa Tengah dalam kajian Undang-Undang No. 23 Tahun 2011 tentang pengelolaan Zakat?

\section{METODE PENELITIAN}

1. Metode Pendekatan

Metode yang digunakan dalam penelitian ini adalah peneliian yuridis normatif, yaitu penelitian yang bersumber pada buku-buku atau literatur dalam pustaka, sedangkan sifat penelitiannya yang menggambarkan seteliti mungkin tentang fakta yang ada yakni ingin mendapatkan gambaran secara tepat dari suatu gejala dalam kehidupan masyarakat atau lembaga, dalam hal ini Lembaga Amil Zakat Masjid Agung Jawa Tengah dan selanjutnya akan dianalisa hubungannya berdasarkan peraturan perundang-undangan yang berlaku dan pendapat para ahli buku-buku atau literatur pustaka.

2. Spesifikasi Penelitian 
Spesifikasi penelitian ini adalah penelitian deskriptif analitis, yaitu suatu penelitian yang berusaha menggambarkan masalah hukum, hukum dan mengkajinya atau menganalisisnya sesuai dengan kebutuhan dari penelitian yang bersangkutan.

Suatu penelitian untuk mencandra atau memberikan masalah hukum tertentu dan berusaha memahami secara mendalam dengan kajian-kajian terhadap masalah hukum dan hal-hal yang melatarbelakangi terjadinya masalah hukum dalam masyarakat. Hasil kajian akan melahirkan pemikiran prospektif dalam kerangka pembaharuan hukum berkaitan dengan masalah hukum yang menjadi fokus penelitian.

3. Sumber Data

Mengingat penelitian ini menggunakan metode pendekatan yurisidis normatif, maka sumber data utama dari data primer dan data sekunder dapat berupa bahan-bahan hukum dan dokumen-dokumen hukum termasuk kasus-kasus hukum yang menjadi pijakan dasar peneliti dalam rangka menjawab permasalahan dan tujuan penelitian.

Jenis data dalam penelitian ini adalah :

a. Bahan Hukum Primer, yaitu Undang-Undang No. 23 Tahun 2011 tentang Pengelolaan Zakat.

b. Bahan Hukum Sekunder, yaitu peraturan-peraturan yang terkait terhadap pelaksanaan dan pengelolaan zakat pada Lembaga Amil Zakat Masjid Agung Jawa Tengah.

c. Bahan Hukum Tersier, yaitu dari kamus-kamus hukum, buku-buku, artikel, jurnal, majalah, karya ilmiah dan diktat-diktat bahan kuliah serta seminar zakat dan dari internet atau media masa lain.

4. Metode Analisis Data

Analisis data yang digunakan dalam penelitian ini adalah metode analisis secara kualitatif normatif yaitu dengan cara mendiskripsikan/ menggambarkan dalam bentuk uraian-uraian dimana penulis 
menganalisis dengan membandingkan antara data dengan Al-Qur'an, hadist, Ijma para Ulama, ketentuan peraturan perundang-undangan atau konsep-konsep teoritis yang dikemukakan oleh para ahli hukum yang terdapat dalam literatur, melalui suatu pembahasan yang komprenhensip dan integral untuk mengetahui korelasi diantaranya.

\section{PEMBAHASAN}

\section{Implementasi Pemberdayaan Zakat di LAZISMA Jawa Tengah untuk Pengentasan Kemiskinan}

Saat ini undang-undang menjadikan zakat sebagai salah satu faktor pengurang penghasilan bruto wajib pajak orang pribadi dan badan usaha yang dimiliki oleh seorang muslim didalam menentukan besarnya penghasilan kena pajak. Hal ini diharapkan dapat meminimalkan beban ganda yang dipikul oleh umat Islam sebagai wajib pajak dan muzzaki. Pola perlakuan tersebut adalah yang optimal untuk mengelola dan mengakomodasi zakat dan pajak, yang kenyataannya kedua hal tersebut merupakan dua sumber pemungutan yang sama-sama dihimpun dari masyarakat. Apabila upaya pengelolaan dan pengakomodasian ini telah berjalan baik, dapat memberikan suatu efek yang produktif dalam pembangunan nasional. Jika dilihat dari fungsi dasarnya membayar zakat bisa disamakan nilainya dengan membayar pajak yakni sama-sama dimaksudkan untuk melaksanakan kewajiban yang bertujan untuk kemaslahatan umat dan bangsa. ${ }^{3}$

Akselarasi penurunan angka kemiskinan di Jawa Tengah bila dibandingkan di propinsi lain di Indonesia tetapi tidak signifikan sehingga kedepannya masih menggunakan APBD. Untuk mengurangi kemiskinan di Jawa Tengah khususnya kota Semarang maka digunakan semacam CSR atau program program khusus baik pemerintah dipusat maupun di daerah. Angka kemiskinan di Jawa Tengah turun dari semula

${ }^{3}$ Agus Budi Yuwono, Kedudukan Potongan Pajak Pribadi Terhadap Zakat Yang Telah Terbayarkan, Jurnal USM Law Review Vol 1 No 1, Magister Hukum Universitas Semarang, Semarang, hlm 84. 
13, 9 persen menjadi 13, 01 persen, namun jumlah warga miskin masih sekitar 4,45 juta jiwa. Angka kemiskinan di Jawa Tengah melebihi angka kemiskinan nasional yang berada dikisaran 10, 70 persen.

Program pemerintah untuk menanggulagi kemiskinan kendalanya karena skala kebijakan, konsep, implementasi dan partisispasi sering tidak tepat sasaran dan tidak adanya evaluasi terhadap keberhasilan program tersebut. Kemudian politik anggaran baik dipusat maupun di daerah belum mendukung program penanggulan kemiskinan. Kendala dari masyarakat miskin itu sendiri dengan pola pikir, perilaku dan budaya yang tidak mendukung perubahan serta sikap mental yang tidak mau berubah. Maka dalam konsep kebijakan penanggulangan kemiskinan, pemberdayaan perlu menjadi pendekatan utama dengan mengutamakan konsep kemandirian. Kunci penanggulangan kemiskinan dengan konsep peningkatan produktifitas yaitu tersedianya pasar bagi produk-produk masyarakat miskin. Untuk menuju masyarakat Jawa Tengah khususnya Kota Semarang semakin sejahtera, berdikari dan hebat perlu ada dukungan dan sinergitas antara pemerintah daerah dengan Koperasi, Dunia Usaha, Perguruan Tinggi, Organisasi Masyarakat Sosial/ LSM dan salah satunya adanya Lembaga Amil Zakat Masjid Agung Jawa Tengah (LAZISMA).

Lembaga Amil Zakat Masjid Agung Jawa Tengah adalah lembaga yang memfokuskan distribusi dana Zakat, Infaq dan Sedekah (ZIS) yang dihimpun melalui berbagai program pemberdayaan ekonomi produktif. Tujuannya untuk masyarakat yang kurang mampu termasuk mustahik (penerima zakat) agar suatu saat mustahik bisa berubah menjadi muzakki (pembayar zakat).

Bahwa LAZISMA Masjid Agung Jawa Tengah dalam menyalurkan dana zakatnya bersifaf konsumtif dan produktif. Konsumtif berarti memenuhi keperluan sehari-hari. Sedangkan zakat produktif adalah pemberian zakat yang dapat membuat para penerimanya menghasilkan sesuatu secara terus menerus, hal ini dapat dilihat dari program-program 
LAZISMA masjid Agung Jawa Tengah dan program-program yang telah terlaksana antara lain :

1. Program LAZISMA masjid Agung Jawa Tengah yang bersifat konsumtif tradisonal tujuannya meringankan beban sehari-hari dari mustahik seperti santunan sosial yang ditujukan kepada fakir mskin, tebar hewan kurban tiap tahun, bingkisan lebaran dan pembagian fitrah pada hari raya Idul Ftri.

2. Untuk program LAZISMA masjid Agung Jwa Tengah dalam pendistribusian konsumtif kreatif programnya seperti santunan dluafa berupa alat-alat perlengkapan sekolah, bantuan dana pendidikan dalam hal kesejahteraan guru dan fasilitas pendidikan, bina desa miskin memfokuskan pada pembinaan rohani, pembangunan fasilitas umum dan pemberdayaan ekonomi masyarakat.

3. Pendistribusian zakat secara produktif konvensional yaitu zakat yang diberikan dalam bentuk barang-barang produktif, dimana dengan barangbarang tersebut, para muzakki dapat menciptakan usaha seperti pemberian bantuan ternak kambing, sapi perahan atau membajak sawah, alat pertukangan dan sebagainya.

4. Untuk pendistribusian zakat secara produktif kreatif adalah zakat yang diwujudkan dalam pemberian modal bergulir, baik untuk pemodalan proyek sosial, seperti pembangunan sekolah, sarana kesehatan atau tempat ibadah maupun sebagai modal usaha untuk pengembangan usaha para pedagang atau pengusaha kecil.

Distribusi zakat konsumsi ditinjau dari hukum Islam merupakan jaminan sosial, sedangkan distribusi zakat secara produktif yaitu sebagai institusi sosial ekonomi untuk mengentaskan mereka yang tergolong penerima zakat (mustahik) dengan cara pendistribusian zakat produktif untuk mengatasi kemiskinan terutama kepada mereka yang memiliki skill untuk dikembangkan. 
Islam mewajibkan kepada setiap individu yang hidup dalam kehidupan sosial agar senatiasa berusaha merealisasikan kehidupan yang layak. Setiap individu wajib mempersiapkan diri sebaik mungkin untuk memiliki taraf hidup yang baik, agar bisa melindungi diri dan masyarakat sekitarnya dari keganasan kemiskinan.

Pengelolaan zakat yang dilakukan secara amanah dan profesional menunjukkan kepada kita betapa peran zakat sebagai solusi masalah keumatan bukan hanya sebuah wacana dan apologi tetapi sebuah kenyataan. “ Rasulullah saw telah mengingatkan dalam sebuah hadist, agar kita menjadi pembela kaum miskin. Tidak boleh kefakiran dibiarkan merajalela dimana-mana karena kefakiran itu sesungguhnya hanya akan menyebabkan dekatnya orang dengan kekufuran.”

Membiarkan kaum miskin tanpa peduli untuk membantu hanya akan mengundang kemurkaan Allah, keberkahan hidup akan dicabut dan berbagai bencana akan datang silih berganti, seperti diungkap dalam hadist.

Kedudukan zakat sejajar dengan kedudukan shalat dalam Al-Qur'an surat Al-Baqarah ayat 43:

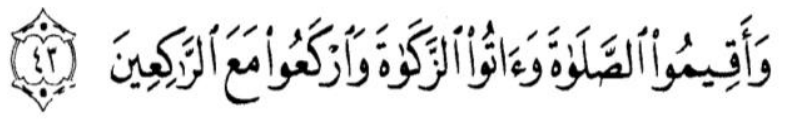

Artinya : "dirikanlah shalat, tunaikanlah zakat dan ruku'lah beserta orangorang yang ruku'. (QS.Al-Baqarah : 43)

\section{II.Kendala dan Solusinya dalam Pelaksanaan Pemberdayaan Zakat sebagai Upaya Pengentasan Kemiskinan}

1. Kendala yang dihadapi dalam pelaksanaan pemberdayaan zakat sebagai upaya pengentasan kemiskinan adalah:

a. Realita yang ada masih banyak muzakki yang masih enggan untuk membayar zakat, terutama para orang-orang kaya masih banyak yang enggan membayar zakat atau hanya membayar sebagian kewajibannya yaitu sebatas zaat fitrah pada hari raya Idul Fitri.

b. Kepercayaan masyarakat (muzakki) kurang terhadap LAZISMA 
dalam transparansi pengelolaan zakat.

c. Sosialisasi kepada masyarakat tentang zakat masih kurang optimal.

2. Solusi yang seharusnya dilakukan LAZISMA masjid Agung Jawa Tengah dalam pemberdayaan zakat sebagai upaya pengentasan kemiskinan antara lain:

a. Melakukan pembinaan pencerdasan muzakki. Disadari bersama bahwa para muzakki belum banyak memahami tentang hakekat penunaian zakat. Selama ini zakat hanya dipahami sebatas zakat fitrah, sehingga ketersediaan zakat maal yang jumlahnya mayoritas belum tergarap. Instrumen formal dari regulasi- regulasi tentang kewajiban zakat bagi muzakki.

b. Penguatan kepada amil zakat untuk bersikap jujur dan profesional. Lembaga zakat ini sama dengan perbankan yaitu bermodalkan kepercayaan. Jadi bagaimana membuat masyarakat bisa percaya pada lembaga dengan berbagai tindakan dan kegiatan yang ada. Sehingga masyarakat dapat melihat fakta yang selama ini dilakukan oleh lembaga akhirnya masyarakat akan tergugah untuk menyalurkan zakatnya melalui lembaga tersebut.

c. Mensinergikan dan saling kerjasama antara lapisan masyarakat, pemerintah, tokoh agama dan juga amil zakat. Dengan hubungan kerjasama yang baik maka akan terasa mudah untuk mendistribusikan zakat keberbagai mustahik. Bentuknya adalah lapisan masyarakat ikut mensupport adanya lembaga zakat dengan menyalurkan dananya ke lembaga tersebut.

\section{E. PENUTUP}

LAZISMA Masjid Agung Jawa Tengah dalam menyalurkan dana Zakatnya bersifat konsumtif dan produktif. Konsumtif berarti memenuhi keperluan sehari-hari. Sedangkan Zakat produktif adalah pemberian Zakat yang dapat membuat para penerimanya menghasilkan sesuatu secara terus 
menerus, hal tersebut dapat dilihat dari program-program LAZISMA Masjid Agung Jawa Tengah dan program-program yang telah terlaksana.

Distribusi Zakat konsumtif ditinjau dari hukum Islam merupakan jaminan sosial. Sedangkan distribusi Zakat secara produktif, yaitu sebagai institusi sosial ekonomi, untuk mengentaskan mereka yang tergolong penerima Zakat (mustahik) dengan cara pendistribusian Zakat produktif untuk mengatasi kemiskinan terutama kepada mereka yang memiliki potensi skil untuk dikembangkan. Kendala yang dihadapi Lembaga Amil Zakat Masjid Agung Jawa Tengah dalam pengentasan kemiskinan di Kota Semarang diantaranya seperti: Realita yang ada masih banyak muzakki yang masih enggan untuk membayar zakat, terutama para orang-orang kaya masih banyak yang enggan membayar zakat atau hanya membayar sebagian kewajibannya, yaitu sebatas zakat fitrah pada hari raya idul fitri saja; Kepercayaan masyarakat (muzakki) kurang terhadap Lazisma dalam transparansi pengelolaan zakat;

\section{DAFTAR PUSTAKA}

\section{Buku}

Didin Hafidhudin, 2002, Zakat dalam Perekonomian Modern, Gema Insani Press, Jakarta

------, 2007, Agar Harta Berkah dan Bertambah : Gerakan Membudayakan Zakat, Infaq, Sedekah dan Wakaf, Gema Insani, Jakarta -, 2003, Islam Aplikatif, Gema Insani, Jakarta

El Madani, 2013, Fiqh Zakat Lengkap, Diva Press, Jogjakarta

Sudikno Mertokusumo, 2009, Penemuan Hukum sebuah Pengantar, Penerbit Liberty, Yogyakarta

Yogyakarta

Sadono Sukirno, 1994, Makro Ekonomi Teori Pengantar, Rajawali Press, Jakarta

Suteki, 2013, Desain Hukum di Ruang Sosial, Thafa Media, Yogyakarta

Satjipto Raharjo, 2000, Ilmu Hukum, Citra Aditya Bakti, Bandung

Soerjono Soekamto dan Sri Mamudji, 1990, Penelitian Hukum Normatif Suatu Tinjauan Singkat, Rajawali Press, Jakarta 
Syaikh Muhammad Shalih at-Utsaimin, 2008, Ensiklopedi Zakat, Kumpulan Fatwa Zakat, Pustaka As-Sunnah, Jakarta

\section{Jurnal}

Abdul Aziz, Pendayagunaan Zakat Sebagai Upaya Pengentasan Kemiskinan, Jurnal Ius Constituendum Vol 1 No 1, Magister Hukum Universitas Semarang, 2016, Semarang. http://dx.doi.org/10.26623/jic.v1i2.552

Agus Budi Yuwono, Kedudukan Potongan Pajak Pribadi Terhadap Zakat Yang Telah Terbayarkan, Jurnal USM Law Review Vol 1 No 1, Magister Hukum Universitas Semarang, Semarang.

\section{Undang-undang}

Undang-Undang Nomor 23 Tahun 2011, tentang Pengelolan Zakat Indonesia Legal Center Publishing, 2007, Undang-Undang Yayasan, CV. Karya Gemilang, Jakarta

PP Nomor 14 Tahun 2014, tentang Pelaksanan UU No. 23 Tahun 2011, tentang Pengelolaan Zakat

Undang-Undang Dasar 1945, beserta Amandemennya, CV. Bringin"55", Solo Peraturan Daerah (Perda) Nomor 7 Tahun 2009 tentang Pengelolaan Zakat.

Tim Penyusun, 2013, Pedoman Penulisan Usulan Penelitian Dan Tesis, Program Studi Ilmu Hukum Pasca Sarjana Universitas Semarang, Semarang.

Keputusan Menteri Agama Republik Indonesia, tentang pelaksanaan UndangUndang No. 23 Tahun 2011, tentang Pengelolaan Zakat

\section{Internet}

Ahmad Dzakirin, http;//ahmeddzakirin.blogspot.com/2010/09/bab-ii-konsepnegara-dalam-islam.html, diakses pada tanggal 21 Nopember 2015 http://desfreidna.blogspot.com/2008/12/hukum-yang-positivistik-JohnAustindan.html diunduh tanggal 27 September 2011.

http://dkpjateng.com/administrasi-umum/publikasi/berita/256-sosialisasipenyaluran-zakat-melalui-badan-amil-daerah

http://sr.coH31.org/NA-RUUPengelolaan Zakat.pdf diunduh tanggal 31 Agustus 2011 